\title{
Effects of Paclobutrazol on Non-enzymatic and Enzymatic Antioxidants during Floral Bud Development in Mango (Mangifera indica L.) cv. Totapuri
}

\author{
G.V. Bindu ${ }^{1 *}$, K.K. Upreti ${ }^{1}$ and G.J. Sathisha ${ }^{2}$ \\ ${ }^{1}$ Division of Plant Physiology \& Biochemistry, ICAR- Indian Institute of Horticultural \\ Research, Hessaraghatta Lake PO, Bengaluru, Karnataka 560089, India \\ ${ }^{2}$ Department of Post Graduate Studies and Research in Biochemistry, Kuvempu University, \\ Shankaraghatta, Shimoga-577451, India \\ *Corresponding author
}

\section{A B S T R A C T}

A study was conducted to investigate the effects of paclobutrazol (PBZ) $\left(1.25 \mathrm{~g} \mathrm{a.i} \mathrm{m}^{-1}\right)$ on the contents of non-enzymatic antioxidants, ascorbic acid, glutathione (GSH) and phenols

Keywords

Mango, paclobutrazol, Nonenzymatic antioxidants, Enzymatic antioxidants, Flower bud development

\section{Article Info}

Accepted:

12 December 2017

Available Online:

10 January 2018 and activities of antioxidant enzymes, peroxidase, catalase, superoxide dismutase and ascorbate peroxidase in buds and leaves of growing shoots of mango cv. Totapuri at four distinct phenological stages numerically represented as 510 (initiation of bud swelling), 511 (Swollen buds, 513 (bud burst) and 515 (panicle emergence) as per BBCH scale. The paclobutrazol treatment increased in non-enzymatic antioxidants, ascorbic acid (5.04$87.61 \%)$, total phenol (5.74-65.65\%) and GSH (5.08-38.7\%) contents buds and leaves and activities enzymatic antioxidants, peroxidase (33.0-266.9\%), SOD (44.3-198.0\%), catalase (68.0-301.6\%), and ascorbate peroxidase (22.8-99.0\%) in buds at various phenological stages. The paclobutrazol induced increase in ascorbic acid and GSH was high at 511 and in total phenols at 513 stages in the developing buds. With respect to bud growth stages, activities of enzymatic antioxidants, peroxidase and ascorbate peroxidase were high at 511 stage and the SOD activity at 510 stage under paclobutrazol treatment. The catalase activity witnessing consistently increasing trends in developing buds was high at panicle emergence (515 stage). There was broad similarity in the trends of non-enzymatic and enzymatic antioxidants antioxidant contents in the developing buds of paclobutrazol untreated and treated trees. From the results, it was apparent that the mango flowering coincides with increase in non-enzymatic and enzymatic antioxidants, and a high antioxidant status induced by paclobutrazol is responsible for its floral responses.

\section{Introduction}

Paclobutrazol, [(2RS,3RS)-1-(4-chlorophenyl) - 4,4-dimethyl-2-(1,2,4-triazol- 1-yl)-pentan3-ol] is an important triazole based plant growth retardant well known for its characteristic activity to reduce plant growth by influencing internodal length, and increase flowering many perennial fruit trees including mango (Kishore et al., 2015). Such responses 
of paclobutrazol are attributed as the consequences of blocking of the oxidative steps with high specificity leading from entkaurene to ent-kaurenoic acid by inhibiting kaurene oxidase activity in the gibberellin biosynthesis pathway (Fletcher et al., 2000). The growth inhibitory action of paclobutrazol is also supported from the reversal of growth inhibitory responses of paclobutrazol by gibberellin treatment (Yadav et al., 2005). Mango (Mangifera indica L.) is one of the important widely cultivated fruit crops of India. However, its production is beset with the problems of biennial bearing, poor fruit set, early fruit drop etc. Use of paclobutrazol is widely recommended practice for increasing flowering and better harvest in mango (Kishore et al., 2015). The beneficial effects of paclobutrazol have been reported as the outcome of modifications in physiological and biochemical processes (Abdel Rahim et al., 2011; Upreti et al., 2013). Upreti et al., (2013) reported decrease in gibberellins concomitant with increase in leaf water potential, ABA and cytokinins associated with increased and early flowering in mango. In another study, Upreti et al., (2014) reported increase in carbohydrates as the result of upregulation in certain carbohydrate metabolizing enzymes by paclobutrazol responsible to floral bud initiation in mango. Further, polyamines ethylene balance has been reported by Bindu et al., (2017) crucial for floral bud growth in mango, with high polyamines and reduced ethylene under paclobutrazol contributory to increased flowering.

Reactive oxygen species (ROS) have been documented to have diversity of roles in the growth and development of plants besides imparting of tolerance to abiotic and biotic stress (Das and Roychoudhary, 2014; Ahmad et al., 2010). Several studies have indicated that controlled production of ROS is vital for cell differentiation and expansion during the morphogenesis of organs (Zinta et al., 2016).
However an imbalance in ROS production has been shown to negatively influence plant growth and development as these may impair cellular metabolism because of their strong tendency to react with cellular biochemical constituents. The plants are reported to be equipped with antioxidant system through the production of antioxidant compounds like ascorbic acid, glutathione, tocopherol, phenolic acid, carotenoids etc and also antioxidant enzymes like peroxidase, catalase, superoxide dismutase (SOD), ascorbate peroxidase, glutathione peroxidase etc to scavenge the ROS, and prevent the possible oxidative damage caused by reactions catalysed by free radicles. (Ahmad et al., 2010). There are good number evidences of involvement of oxidative enzymes with floral abscission and senescence in number of crops (Stead and van Doorn, 1994) and stress tolerance (Das and Roychoudhary, 2014) in plants. Limited studies have been undertaken on the involvement of antioxidant system in floral bud differentiation and floral growth initiation. In one of the studies (Salem et al., 2011) reported significant variations in antioxidant properties in different floral development stages of Carthamus tinctorius, and the highest antioxidant activity was obtained at full flowering. In the present investigation, we studied the effects of paclobutrazol on some non-enzymatic and enzymatic antioxidant compounds at different phenological stages of floral bud growth in mango cv. Totapuri with a view to delineate their role in paclobutrazol induced flowering.

\section{Materials and Methods}

The studies were conducted on 18 years old grafted trees of a regular bearing mango cv. Totapuri grown at 10x10 m spacing during the years 2014 - 2015 at the experimental farm of ICAR - Indian Institute of Horticultural Research, Hessaraghatta, Bengaluru. The average canopy diameter of the trees was 
around $8.0 \mathrm{~m}$. During experimental period, the monthly average maximum and minimum temperatures ranged between 20.2 and $28.1^{\circ} \mathrm{C}$ and average relative humidity was $63.2 \%$ at $1400 \mathrm{~h}$. Recommended package of practices were adopted for the day-to-day orchard maintenance. Single recommended dose of paclobutrazol (Zeneca Limited, Surry, UK, 25 $\% \mathrm{w} / \mathrm{v}$ ) at $1.25 \mathrm{~g}$ a.i. per $\mathrm{m}$ canopy diameter was applied as soil drenching treatment to mango trees by spreading its aqueous solution (4.0 litres) uniformly in a circular band $(25 \mathrm{~cm}$ wide) around the tree at $1.0 \mathrm{~m}$ radial distance from the base of tree trunk during 3rd week of August. The untreated trees (control) were irrigated by similar volume of water. Four trees were kept under paclobutrazol treatment while another four trees served as control. The experiment was conducted using RBD.

The terminal shoots measuring about $20 \mathrm{~cm}$ length from current year growth were labelled in different directions in the treated and control trees immediate after paclobutrazol treatment. Sampling for apical buds and leaves was carried out at periodic intervals from $3^{\text {rd }}$ week of September for free non-enzymatic antioxidants and enzymatic antioxidants at four phenological stages of floral bud growth characterized as 510 (initiation of bud swelling), 511 (swollen buds), 513 (bud burst) and 515 (panicle emergence) as per the pheno - phase guide chart suggested by Rajan et al., (2011). The sampled buds and leaves under were immediately frozen in liquid nitrogen and then stored in a- $70^{\circ} \mathrm{C}$ freezer for the analysis.

\section{Ascorbic acid}

$2 \mathrm{~g}$ of buds and leaf samples were homogenised with $4 \%$ oxalic acid solution, squeezed through a muslin cloth and volume was made upto $50 \mathrm{ml}$. A $10 \mathrm{ml}$ of aliquot from this was pipetted out and titrated against standard 2,6-D diclorophenol indophenol
(DCPIP) dye solution. The ascorbic acid was calculated from the volume of DCIP solution used according to Ruck (1963) and values were expressed at $\mathrm{mg} / \mathrm{g}$.

\section{Total phenols}

Total phenol content was determined by the Folin-Ciocalteu method of Bray and Thorpe (1954). A $500 \mu 1$ of sample extract $(12 \mathrm{mg} / \mathrm{mL})$ was diluted to $1.0 \mathrm{~mL}$ with distilled water and mixed thoroughly with $0.5 \mathrm{~mL}$ of Folin-Ciocalteu reagent for $2 \mathrm{~min}$. After addition of $1.0 \mathrm{~mL}$ of $20 \%(\mathrm{w} / \mathrm{v})$ sodium carbonate, the mixture was allowed to stand for $30 \mathrm{~min}$ in the dark, and absorbance was measured at $700 \mathrm{~nm}$. The total phenols content was calculated using gallic acid as standard and results were expressed as mg (gallic acid) per $g$.

\section{Reduced glutathione}

The method of Moron et al., (1979) was adopted to determine the amount of reduced glutathione (GSH) content in buds and leaves. $1.0 \mathrm{~g}$ of sample macerated with $5.0 \mathrm{ml} 5 \%$ TCA and contents centrifuged at $10,000 \mathrm{rpm}$ for 10 min at $4{ }^{\circ} \mathrm{C}$ and the supernatant was separated out. To $0.2 \mathrm{ml}$ of supernatant, $1.0 \mathrm{ml}$ of $50 \mathrm{mM}$ phosphate buffer $(\mathrm{pH} 6.8)$ followed by $2.0 \mathrm{ml}$ of freshly prepared DTNB (Ellman's reagent) solution was added and the absorbance of yellow colour formed was recorded at $412 \mathrm{~nm}$ after $10 \mathrm{~min}$. The GSH content was expressed as $\mathrm{mg} \mathrm{GSH} / \mathrm{g}$.

\section{Catalase activity}

The catalase activity was assessed by measuring the absorbance at $240 \mathrm{~nm}$ upto 3 $\mathrm{min}$ at $30 \mathrm{~s}$ time interval using procedure described by Masia (1988). Three millilitres assay reaction mixture contained $0.067 \mathrm{M}$ phosphate buffer ( $\mathrm{pH} 7.0$ ), $0.2 \mathrm{ml}_{2} \mathrm{H}_{2}$ and $0.2 \mathrm{ml}$ enzyme extract. The catalase activity 
was calculated taking unit activity as the amount of enzyme decomposing $1.0 \mathrm{mmol}$ of $\mathrm{H}_{2} \mathrm{O}_{2}$ per min and expressed as units/min/mg protein.

\section{Peroxidase activity}

The Peroxidase activity was determined spectrophotometrically according to the procedure of Malik and Singh (1980). The reaction mixture in a $5.0 \mathrm{ml}$ final volume contained $100 \mathrm{mM}$ phosphate buffer $(\mathrm{pH} \mathrm{7.0)}$, $0.1 \mathrm{~N}$ pyrogallol, $0.02 \% \mathrm{H}_{2} \mathrm{O}_{2}$ and $2.0 \mathrm{ml}$ of enzyme extract. The oxidation of progallol to purpurogallin was measured at $434 \mathrm{~nm}$ and the enzyme activity was expressed as units/min/mg protein.

\section{Superoxide dismutase (SOD) activity}

SOD activity was assayed by monitoring the inhibition of photochemical reduction of nitro blue tetrazolium (NBT) according to Giannopolitis and Ries (1977) with some modifications. The reaction mixture $(3.0 \mathrm{ml})$ containing $50 \mathrm{mM}$ Na-PO4 buffer (pH 7.8), 1 mmol EDTA, $149 \mathrm{~g} / \mathrm{mol}$ L. methionine, $1 \mathrm{mmol}$ NBT, $0.2 \mathrm{mmol}$ riboflavin and $40 \mu \mathrm{l}$ $(200 \mathrm{mg} / \mathrm{ml})$ enzyme extract was illuminated for 10-12 min using $40 \mathrm{~W}$ fluorescent bulb. A control tubes contained components the same as described above, except that of crude enzyme replaced by an equal volume of phosphate buffer ( $\mathrm{pH}$ 7.8). One unit of SOD activity was defined as the amount of enzyme required to cause $50 \%$ inhibition of the reduction of NBT as monitored at $560 \mathrm{~nm}$ and the enzyme activity was expressed as units/min/mg protein.

\section{Ascorbate peroxidase activity}

The ascorbate peroxidase activity was estimated employing the procedure described by Jiang and Huang (2001). The enzyme solution was prepared by grinding $1.0 \mathrm{~g}$ tissue in $5.0 \mathrm{ml}$ of extraction buffer $(0.05 \mathrm{M}$ phosphate buffer, $\mathrm{pH}$ 7.0, 8.0\% glycerol, 1.0 $\mathrm{mM}$ EDTA, and $1 \mathrm{mM}$ ascorbic acid). PVP $(0.3 \mathrm{~g} / \mathrm{g}$ tissue $)$ was also added during enzyme preparation for removing phenolics. The extract was centrifuged at $10000 \mathrm{rpm}$ for 15 min. The enzyme solution $(5-20 \mu \mathrm{l})$ was added to a $3.0 \mathrm{ml}$ reaction mixture of $50 \mathrm{mM}$ phosphate buffer ( $\mathrm{pH} 7.0)$, ascorbic acid (1 $\mathrm{mM})$, and $\mathrm{H}_{2} \mathrm{O}_{2}(0.3 \%)$, and the decrease in absorbance $\left(2.9 \mathrm{mM}^{-1} \mathrm{~cm}^{-1}\right)$ for the first $30 \mathrm{~s}$ of the reaction was used to calculate ascorbate peroxidase activity and the enzyme activity was expressed as unit enzyme/min/mg protein.

\section{Proteins}

The protein content was determined by the procedure of Lowry et al., (1951) using bovine serum albumin as standard.

\section{Statistical analysis}

Statistical analysis software (SAS) for all statistical analysis and the data was expressed as mean of replicates $\pm \mathrm{SE}$.

\section{Results and Discussion}

\section{Changes in non-enzymatic antioxidants}

In the paclobutrazol untreated trees, the ascorbic acid and GSH contents in buds and phenols content both in buds and leaves varied significantly at different phenological stages, and the ascorbic acid and GSH contents were high in buds while total phenols contents in leaves (Table 1). With respect to bud development stages, the ascorbic acid contents in the paclobutrazol untreated trees increased from 509 to 510 stage and total phenols upto 511 stage in the buds and decline subsequently. In contrast, GSH content exhibited consistent increasing trends as buds approached panicle emergence stage (513 stage) (Table 1). Following paclobutrazol treatment, the mango trees responded with 
significant increase in ascorbic acid (5.04$87.61 \%)$, total phenol (5.74-65.65\%) and GSH (5.08-38.7\%) contents in buds as well as in leaves at various phenological stages, and buds were more responsive than the leaves (Table 1). The paclobutrazol induced increase in ascorbic acid and GSH was high at 511 and in total phenols at 513 stages in the developing buds. Furthermore, there was broad similarity in the trends of non-enzymatic antioxidant contents in the developing buds of paclobutrazol untreated and treated trees.

\section{Changes in enzymatic antioxidants}

In the paclobutrazol untreated trees, peroxidase and catalase activities in developing buds high at 510 declined gradually by 513 stage, while ascorbate peroxidase activity exhibited contrasting trends. The leaves of untreated trees did not show distinct pattern in terms of changes in these enzymes with respect bud development stages (Table 2). In the paclobutrazol treated trees, distinct induction in the activities of peroxidase, SOD, catalase and ascorbate peroxidase was apparent at various bud growth stages. The paclobutrazol treatment in general showed distinct induction in peroxidase, SOD, catalase, and ascorbate peroxidase activities almost by $33.0-266.9 \%$, $44.3-198.0 \%, 68.0-301.6 \%$ and $22.8-99.0 \%$ respectively in buds as compared to untreated trees. However, in leaves changes in these enzymes by paclobutrazol were inconsistent at different phenological stages. With respect to bud growth stages, the peroxidase and ascorbate peroxidase activities in paclobutrazol treated trees were high at 511 stage and the SOD activity at 510 stage. The catalase activity witnessing consistently increasing trends in developing buds was high at panicle emergence (513 stage) (Table 2).

Non-enzymatic antioxidants such as ascorbic acid, GSH and phenolic acid are important low molecular weight non-enzymatic cellular detoxifying biochemical constituents involved in many physiological processes regulatory to reproductive development. While ascorbic acid is shown effective in influencing induction of flowering by modulating photosynthesis and biosynthesis of certain phytohormones (Barth et al., 2006), GSH involvement in flowering by possible modulations in cellular redox state to achieve minimal ROS levels (Ogawa 2001, 2005). Besides, GSH action is reported to be mediated indirectly by regenerating adequate quantities of ascorbic acid through GSHascorbic cycle (Christine and Halliwell, 1976). Similarly, phenolic acids have been reported to play a role floral development through regulations in ROS production (Sood and Nagar 2003, Schmitzer et al., 2009). Thus high levels of such non-enzymatic antioxidants with during the initial stage of floral bud formation and increase in their content by paclobutrazol evident from the results reveals importance of these molecules floral growth in mango. Such increases may be consequences of inductions in enzymes involved in their biosynthesis or better availability of precursor linked to their biosynthesis.

In support of our results, Vasudev and Gopal (1977) in Coffea arabicaand Dogra and Sinha (1979) in Phyllanthus simplex Retz reported high ascorbic acid content in their floral buds. Similarly, the paclobutrazol increasing ascorbic acid is also reported in citrus lemon juice (Jain et al., 2002) and GSH in Vigna unguiculata (Manivannan et al., 2008) and carrot (Gopi et al., 2007). Ahmad and Tahir (2016) reported increase in phenolic acid content in buds towards anthesis in Iris versicolor and Iris japonica plants suggesting a role of phenols in flowering. Mert et al., (2013) also reported involvement phenolic acid in flowering in Olea europaea L. Srilatha et al., (2016) reported increase in phenolic acid in mango following paclobutrazol application. 
Table.1 Effects of paclobutrazol (PBZ) on the non-antioxidant contents in buds and leaves at various developmental stages of bud in mango cv. Totapuri (Data represent mean \pm SD of 4 replications)

\begin{tabular}{|l|l|c|c|c|c|c|c|c|c|}
\hline \multirow{2}{*}{$\begin{array}{l}\text { Non- } \\
\text { enzymatic } \\
\text { antioxidants }\end{array}$} & & \multicolumn{4}{|c|}{ Buds } & \multicolumn{3}{c|}{ Leaves } \\
\hline $\begin{array}{l}\text { Ascorbic acid } \\
\text { (mg/g) }\end{array}$ & $\mathbf{- P B Z}$ & $45.6 \pm 3.12$ & $53.8 \pm 4.78$ & $33.1 \pm 4.21$ & $28.1 \pm 3.15$ & $13.9 \pm 1.19$ & $9.9 \pm 0.86$ & $10.3 \pm 1.22$ & $10.8 \pm 0.09$ \\
\hline Total phenols & $\mathbf{+ P B Z}$ & $61.4 \pm 4.03$ & $75.4 \pm 6.92$ & $62.1 \pm 3.63$ & $40.7 \pm 3.45$ & $14.6 \pm 1.62$ & $13.8 \pm 1.13$ & $11.5 \pm 1.04$ & $12.9 \pm 1.16$ \\
\hline (mg/g) & $\mathbf{- P B Z}$ & $12.21 \pm 1.36$ & $19.16 \pm 1.46$ & $21.93 \pm 1.67$ & $15.78 \pm 1.32$ & $28.92 \pm 1.37$ & $43.54 \pm 5.63$ & $49.22 \pm 5.24$ & $35.17 \pm 3.15$ \\
\hline $\begin{array}{l}\text { Glutathione } \\
\text { (mg/g) }\end{array}$ & $\mathbf{+ P B Z}$ & $14.96 \pm 1.59$ & $29.98 \pm 3.09$ & $34.87 \pm 4.11$ & $26.14 \pm 2.17$ & $32.11 \pm 4.13$ & $47.58 \pm 6.32$ & $45.59 \pm 2.93$ & $33.15 \pm 2.32$ \\
\hline
\end{tabular}

Numerical codes of bud developmental stages: 510 (bud swelling), 511 (swollen buds), 513 (bud burst) and 515 (panicle emergence) according to standard BBCH scale

Table.2 Effects of paclobutrazol on the activities enzymatic antioxidants in buds and leaves at various developmental stages of bud in mango cv. Totapuri (Data represent mean \pm SD of 4 replications)

\begin{tabular}{|c|c|c|c|c|c|c|c|c|c|}
\hline \multirow{2}{*}{$\begin{array}{l}\text { Enzymatic antioxidant } \\
\text { activity }\end{array}$} & & \multicolumn{4}{|c|}{ Buds } & \multicolumn{4}{|c|}{ Leaves } \\
\hline & & 510 & 511 & 513 & 515 & 510 & 511 & 513 & 515 \\
\hline \multirow{2}{*}{$\begin{array}{l}\text { Peroxidase } \\
\text { (units/min/mg protein) }\end{array}$} & -PBZ & $6.48 \pm 0.52$ & $5.22 \pm 0.41$ & $1.94 \pm 0.13$ & $2.15 \pm 0.23$ & $1.65 \pm 0.14$ & $1.97 \pm 0.12$ & $2.86 \pm 0.19$ & $2.41 \pm 0.38$ \\
\hline & $+\mathrm{PBZ}$ & $8.62 \pm 0.71$ & $11.96 \pm 1.28$ & $6.91 \pm 0.23$ & $4.99 \pm 0.42$ & $1.67 \pm 0.09$ & $1.66 \pm 0.14$ & $3.90 \pm 0.23$ & $4.16 \pm 0.21$ \\
\hline \multirow{2}{*}{$\begin{array}{l}\text { SOD (units/min/mg } \\
\text { protein) }\end{array}$} & -PBZ & $8.12 \pm 0.91$ & $11.13 \pm 1.05$ & $18.11 \pm 1.52$ & $20.12 \pm 2.17$ & $3.13 \pm 0.21$ & $5.86 \pm 0.63$ & $3.36 \pm 0.34$ & $3.06 \pm 0.14$ \\
\hline & $+\mathrm{PBZ}$ & $19.98 \pm 2.31$ & $33.15 \pm 3.08$ & $36.64 \pm 3.79$ & $29.00 \pm 2.15$ & $4.06 \pm 0.46$ & $7.89 \pm 0.61$ & $4.01 \pm 0.49$ & $3.82 \pm 0.19$ \\
\hline \multirow{2}{*}{$\begin{array}{l}\text { Catalase (units/min/mg } \\
\text { protein) }\end{array}$} & -PBZ & $0.741 \pm 0.09$ & $0.59 \pm 0.06$ & $0.31 \pm 0.04$ & $0.26 \pm 0.06$ & $0.29 \pm 0.05$ & $0.21 \pm 0.01$ & $0.18 \pm 0.02$ & $0.15 \pm 0.01$ \\
\hline & $+\mathrm{PBZ}$ & $1.25 \pm 0.22$ & $2.05 \pm 0.14$ & $1.15 \pm 1.04$ & $1.03 \pm 0.08$ & $0.35 \pm 0.06$ & $0.30 \pm 0.02$ & $0.35 \pm 0.07$ & $0.26 \pm 0.06$ \\
\hline \multirow{2}{*}{$\begin{array}{l}\text { Ascorbate peroxidase } \\
\text { (units/min/mg protein) }\end{array}$} & -PBZ & $2.35 \pm 0.17$ & $2.49 \pm 0.28$ & $2.83 \pm 0.24$ & $3.71 \pm 0.26$ & $8.33 \pm 0.74$ & $15.61 \pm 1.28$ & $9.76 \pm 0.85$ & $9.06 \pm 0.63$ \\
\hline & $+\mathrm{PBZ}$ & $1.81 \pm 0.12$ & $4.37 \pm 0.32$ & $5.62 \pm 0.45$ & $6.96 \pm 0.43$ & $9.38 \pm 0.49$ & $22.68 \pm 2.03$ & $7.82 \pm 0.52$ & $11.85 \pm 0.86$ \\
\hline
\end{tabular}

Numerical codes of bud developmental stages: 510 (bud swelling), 511 (swollen buds), 513 (bud burst) and 515 (panicle emergence) according to standard $\mathrm{BBCH}$ scale 
Thus increase in intracellular contents of ascorbic acid, GSH and phenolic acids as a consequence of altered cellular metabolic function is important attribute of paclobutrazol for floral bud formation in mango.

Besides non-enzymatic antioxidants, the cellular defense system also consists of antioxidant enzymes such as peroxidase, catalase and ascorbate peroxidase that maintain the cellular redox status and help in protecting cell membrane integrity by inactivating ROS produced during metabolicchanges (Ahmad et al., 2010). While the peroxidases are class of oxidoreductase enzymes that catalyse the oxidation of compounds by decomposition of $\mathrm{H}_{2} \mathrm{O}_{2}$ or organic peroxides, the catalase helps in protecting cells from oxidative damage by catalyzing the decomposition of $\mathrm{H}_{2} \mathrm{O}_{2}$. Similarly, ascorbate peroxidase functions in the $\mathrm{H}_{2} \mathrm{O}_{2}$-detoxification system through ascorbate-glutathione cycle by utilizing ascorbic acid as electron donor. SOD on the other hand helps in catalyzing the dismutation of the superoxide $\left(\mathrm{O}_{2}{ }^{-}\right)$radical either into molecular oxygen $\left(\mathrm{O}_{2}\right)$ or hydrogen $\mathrm{H}_{2} \mathrm{O}_{2}$. It is documented that onset of floral induction requires some stress factors. During phase transition from vegetative to reproductive, the cellular antioxidant status of plants tends to increases, suggesting that plants being exposed to stressful conditions for the onset of reproductive growth (Gielis et al., 1999, Wada and Takeno 2010). Thus increase in antioxidant enzymes activities during bud growth and their inductions by paclobutrazol indicates possible production of high levels of ROS during floral process due to high metabolic demand and/possible by stress factors, and their inactivation by inductions in such enzymes. The studies of Lokhande et al., (2003) further support our contention that production of ROS like $\mathrm{H}_{2} \mathrm{O}_{2}$ is important to flower induction. Wang and Faust (1994) and
Wang et al., (1991) reported increase in SOD and catalase activities during initial bud development stages in apple. Gohari et al., (2015) suggested that antioxidant enzymes are one of the important biochemical factors for transition of vegetative growth to flowering. In support of increase in enzyme activities by paclobutrazol, Moradi et al., (2017) in pomegranate and Hu et al., (2017) in Chinese Bay berry reported increase in antioxidant enzymes by paclobutrazol under stress condition. Saxena et al., (2014) also implicated induction in certain antioxidant enzymes by paclobutrazol crucial for flower promotion in mango.

From these findings, it is concluded that the mango flowering coincides with increase in non-enzymatic and enzymatic antioxidants, and strong antioxidant status by paclobutrazol in buds is responsible for its floral responses.

\section{Acknowledgements}

The authors are thankful to the Director of the institute for encouragement and support during the study. We gratefully acknowledge the financial support from NAIP, ICAR, New Delhi

\section{References}

Abdel Rahim, A. O. S., Elamin, O. M. and Bangerth, F. K. 2011. Effects of paclobutrazol (PBZ) on floral induction and associated hormonal and metabolic changes of biennially bearing mango (Mangifera indica L.) cultivars during off year. ARPN J. Agric. Biol. Sci.6: 5567.

Ahmad, P., Jaleel, C.A., Salem, M.A., Nabi, G., and Sharma, S. 2010. Roles of enzymatic and nonenzymatic antioxidants in plants during abiotic stress. Crit. Rev. Biotechnol.30: 161-75.

Ahmad, S.S. and Tahir, I. 2016. Reported 
increase in phenols from bud stage to anthesis in I. versicolor and I. Japonica plants suggesting a role of phenols in flowering. Indian Journal of Plant Physiology 22(1):

Barth, C., DeTullio, M. and Conklin, P.L. 2006. The role of ascorbic acid in the control of flowering time and the onset of senescence. J. Expl. Bot. 57:16571665.

Bindu, G.V., Sharma, Maryada and Upreti, K.K. 2017. Polyamine and ethylene changes during floral initiation in response to paclobutrazol in mango (Mangifera indica L.). Internat. J. Environ.Agri. Res.3: 34-40.

Bray H.G. and Thorpe W.V. 1954. Analysis of Phenolic compounds of interest in metabolism. Methods Biochem Anal. $1: 27-52$

Christine H. F. and Halliwell B. 1976. The presence of glutathione and glutathione reductase in chloroplasts: A proposed role in ascorbic acid metabolism. Planta

Das, K. and Roychoudhury, A. 2014. Reactive oxygen species (ROS) and response of antioxidants as ROSscavengers during environmental stress in plants. Front. Environ. Sci., 02: doi https://doi.org/10.3389/fenvs.2014.0005 3

Dogra, J. and Sinha, S.K. 1979. Variation in the ascorbic acid content of Leaves and fruits of Phyllanthus simplex, Retz, duringvarious stages of development. Comp. Physiol. Ecol.4:98-100.

Fletcher, R. A., Gilley, A., Davis, T. D., and Sankhla, N. 2000. Triazoles as plant growth regulators and stress protectants. Hortic. Rev. 24: 55-138.

Giannopolitis, C.N. and Ries, S.K. 1977. Superoxide dismutases: I. Occurrence in higher plants. Plant Physiol. 59:309314.

Gielis J, Goetghebeur P, and Debergh P. 1999. Physiological aspects and experimental reversion of flowering in Fargesia murieliae (Poaceae, Bambusoideae). System.Geogr. Plants. 12: 147-158.

Gohari, G., Dadpoor M., Movafeghi A., Zaree, F., Habib N. and Kazemnia D. 2015. Seasonal variation of some antioxidant enzymes in apple (Red delicious) leaves and buds during transition to flowering. J. Biodiver. Environ. Sci. 6: 234-240.

Gopi, R., Jaleel, C.A., Sairam, R., Lakshmanan, G.M., Gomathinayagam, M., and Panneerselvam, R. 2007. Differential effects of hexaconazole and paclobutrazol on biomass, electrolyte leakage, lipid peroxidation and antioxidant potential of Daucus carota L. Colloids Surf B Biointer. 60:180-186. Hu, Y. Yu, W., Liu, T., Shafi, M., Song, L., Du, X., Huang, X., Yue, Y. and Wu J. 2017. Effects of paclobutrazol on cultivars of Chinese bayberry (Myrica rubra) under salinity stress. Photosynthetica.55: 443-453.

Jain S K, Singh R and Mishra K.K. 2002. Effect of paclobutrazol on growth, yield and fruit quality of lemon (Citrus limon). Ind. J. Agric. Sci.72: 488-489.

Jiang, Y.W. and Huang, B. 2001. Effects of calcium on antioxidant activities and water relations associated with heat tolerance in two cool-season grasses. $J$. Expt. Bot. 52:341-349.

Kishore, K., Singh, H.S., Kurian, R.M. 2015. Paclobutrazol use in perennial fruit crops and its residual effects: $A$ review.Ind. J. Agric.Sci. 85: 863-872.

Lokhande SD, Ogawa K, Tanaka A, Hara T. 2003. Effect of temperature on ascorbate peroxidase activity and flowering of Arabidopsis thaliana ecotypes under different light conditions. J. Plant Physiol. 160: 57-64.

Lowry, O.H., Rosebrough, N.J., Farr, A.L., Randall, R.J. 1951. Protein 
measurement with the Folin phenol reagent. J. Biol. Chem. 193:265-75.

Malik, C.P. and Singh, M.B. 1980. Plant Enzymology and Histoenzymology: A text manual. Kalyani Publisher, New Delhi. P. 50

Manivannan P., Jaleel, C.A., Kishorekumar, A., Sankar, B., Somasundaram, R. and Panneerselvam R. 2008. Protection of Vigna unguiculata (L.) Walp. plants from salt stress by paclobutrazol. Colloids Surf B: Biointer. 61: 315-318.

Masia, A. 1988. Superoxide dismutase and catalase activities in apple fruit during ripening and post-harvest and with special reference to ethylene. Physiol. Pl. 104: 668-672.

Mert, CE, Barut E. and Ipek, A. 2013. Quantitative seasonal changes in the leaf phenolic content related to the alternate bearing patterns of olive (Olea europea L. Cv. Gemlik). J. Agric. Sci. Tech. 15: 995-1006.

Moradi, S., Baninasab, B., Gholami M. and Ghobadi C. 2017. Paclobutrazol application enhances antioxidant enzyme activities in pomegranate plants affected by cold stress. J. Hortic. Sci. Biotechnol. 92:65-71.

Moron M.S, Depierre J.W and Mannervik B. 1979. Levels of glutathione, glutathione reductase and glutathione S-transferase activities in rat lung and liver. Biochim Biophys Acta. 582:67-78.

Ogawa K, Tasaka Y, Mino M, Tanaka Y and Iwabuchi M. 2001. Association of glutathione with flowering in Arabidopsis thaliana. Plant Cell Physiol. 42: 524-30.

Ogawa K. 2005. Glutathione-associated regulation of plant growth and stress responses. Antioxid Redox Signal. 7:973-981.

Rajan, S., Tiwari, D., Singh, V. K., Saxena, P., Singh, S., Reddy, Y. T. N. 2011. Application of extended $\mathrm{BBCH}$ scale for phenological studies in mango (Mangifera indica L.). J. Applied Hort. 13: 108-114.

Ruck, J.A. 1963. Chemical Methods for Analysis of Fruit and Vegetable products. Canada Department of Agriculture, contribution No. B 7, Research Station, Summerland, 60p.

Salem, N., Msaada, K., Hamdaoui, G., Ferid Limam, F. and Marzouk, B. 2011. Variation in Phenolic composition and antioxidant activity during flower development of safflower (Carthamus tinctorius L.). J. Agric. Food Chem., 59: 4455-4463

Saxena P, Singh VK, Pathak N. 2014. Antioxidative enzymes and biochemical changes in paclobutrazol induced flowering in mango (Mangifera indica L.) cultivars. J. Environ. Biol. 35(6):1061-6.

Schmitzer V., Veberic, R., Osterc G. and Stampar F. 2009. Changes in the Phenolic Concentration during Flower Development of Rose 'KORcrisett'. $J$. Amer. Soc. Hort. Sci. 134: 491-496.

Sood, S. and Nagar, P.K. 2003. Changes in abscisic acid and phenols during flower development in two diverse species of rose. Acta Physiol. Plant. 25: 411-416.

Srilatha, V., Reddy, Y. T. N., Upreti, K. K., Venugopalan, R. and Jayaram, H. L 2016. Responses of pruning and paclobutrazol in mango (Mangifera indica L.): changes in tree vigour, flowering and phenols. J. Applied Hort. 18:148-153.

Stead A.D. and van Doorn. W.G. 1994. Strategies of flower senescence-A review. In: Scott R.J. and Stead A.D., eds. Molecular and Cellular Aspects of Plant Reproduction. Cambridge, UK: Cambridge University Press. pp. 215238.

Upreti, K. K., Reddy, Y. T. N., Shivu Prasad, S. R., Bindu, G. V. and Jayaram, H. L. 
2013. Hormonal changes in response to paclobutrazol induced early flowering in mango cv. Totapuri. Scientia Hort. 150: 414-418.

Upreti, K.K., Shivu Prasad, S.R., Reddy, Y. T. N., Rajeshwara, A. N. 2014. Paclobutrazol induced changes in carbohydrates and some associated enzymes during floral initiation in mango (Mangifera indica L.) cv. Totapuri. Ind. J. Plant Physiol. 19: 317323.

Vasudev N. and Gopal N.H. 1977. Physiological studies on flowering in coffee (Coffea arabica) under south Indian conditions: Changes in iron and copper enzymes and abscisic acid during flower bud enlargement and anthesis. Turriaba 27: 353-359

Wada K.C and Takeno K. 2010. Stress induced flowering. Plant Signal. Behav. 5: $944-947$.
Wang S.Y and Faust M. 1994. Changes in the Antioxidant system associated with bud break In: Anna Apple (Malus domestica Borkh.) buds. J. Amer. Soc. Hort. Sci.119: 735-741.

Wang S.Y, Jiao H.J and Faust M. 1991. Changes in superoxide dismutase activity during thidiazuron -induced budbreak of apple. Hort Science 26: 1202-1204

Yadav, R.K., Rai, N., Yadav, D.S., Asati, B.S. 2005. Use of paclobutrazol in horticultural crops-A review. Agric. Rev. 26: 124-132.

Zinta, G., Khan, A., Hamada AbdElgawad, H., Verma,V., and Ashish Kumar Srivastava, A.K. 2016. Unveiling the Redox Control of Plant Reproductive Development during Abiotic Stress. Front. Plant Sci., 7: doi: https://doi.org/10.3389/fpls.2016.00700.

\section{How to cite this article:}

Bindu, G.V., K.K. Upreti and Sathisha, G.J. 2018. Effects of Paclobutrazol on Non-enzymatic and Enzymatic Antioxidants during Floral Bud Development in Mango (Mangifera indica L.) cv. Totapuri. Int.J.Curr.Microbiol.App.Sci. 7(01): 1608-1617. doi: https://doi.org/10.20546/ijcmas.2018.701.195 